\title{
REGENERATION, GROWTH AND NUTRIENT PARTITIONING OF THREE WOODY SPECIES ON DEGRADED TROPICAL RAINFOREST LAND
}

\author{
Choula, F. ${ }^{1}$ - TAFFouO, V. D. ${ }^{1 *}$ - Priso, R. J. ${ }^{1}$ - EtAME, J. ${ }^{1}-$ ZAPFACK, L. ${ }^{2}-\mathrm{NTSOMBOH}$ \\ NTSEFONG, G. ${ }^{2,3}-$ NGANE, K. B. ${ }^{4}$ \\ ${ }^{1}$ Faculty of Science, University of Douala, B. P. 24157 Douala, Cameroon \\ (e-mail:fchoula@yahoo.fr,dtaffouo@yahoo.com,r_priso@yahoo.fr,etame.jacques@yahoo.fr) \\ ${ }^{2}$ The Department of Plant Biology, Faculty of Science, University of Yaounde 1, Cameroon \\ (e-mail: ntsomboh@yahoo.fr, lzapfack@yahoo.fr) \\ ${ }^{3}$ Institute of Agricultural Research for Development (IRAD), La Dibamba, B. P. 243 Douala, \\ Cameroon \\ ${ }^{4}$ Institute of Agricultural Research for Development (IRAD), Ekona Regional Agricultural \\ Research Center, B. P. 25 Buea, Cameroon \\ (e-mail:nganekoben@yahoo.co.uk) \\ *Corresponding author \\ e-mail:vtaffouo@yahoo.com; phone: +237675900350 \\ (Received 25 $5^{\text {th }}$ Sep 2016; accepted $28^{\text {th }}$ Nov 2016)
}

\begin{abstract}
Forestry provides the conditions for regeneration of forest species, shortened vegetation succession and duration to reach colonization climax. The impact of inorganic fertilizers [urea $(46 \% \mathrm{~N})$, single superphosphate $(33.5 \% \mathrm{P})$ and muriate of potash $(49.8 \% \mathrm{~K})]$ single or in combination on growth, regeneration rate and nutrient partitioning in woody species (Millettia laurentii, Microberlinia bisulcata and Lophira alata) was investigated. Some growth parameters [number of leaves (NL), shoot length (SL), stems diameter $(\mathrm{SD})$ and number of branches $(\mathrm{NB})]$, regeneration rate and nutrient uptake $(\mathrm{N}, \mathrm{P}, \mathrm{K}, \mathrm{Ca}$ and $\mathrm{Mg}$ ) were determined. $M$. laurentii and L. alata showed higher regeneration rates (82.40 and $84.80 \%$ respectively) than those of $M$. Bisulcata (46.40\%) 123 DAP. The NL, SL, SD, NB and N, P, K, Ca and $\mathrm{Mg}$ uptake in $M$. Laurentii plants were positively influenced by inorganic-N, P, K and NPK fertilizers compared to those of L. alata and M. Bisulcata 331 DAP. The highest accumulation of N, P, K, Ca and $\mathrm{Mg}$ concentrations was found in leaves of all the species. These results suggest that $M$. laurentii could adapt to soil nutrient amendment and can be used as catalyst for reforestation of degraded tropical rainforest land. The specific combination (NPK) was found as efficient fertilizer to enhance the woody species regeneration.
\end{abstract}

Keywords: biodiversity, deteriorated soil, forestry, mineral nutrition, restoration

\section{Introduction}

Biodiversity is the occurrence of different types of ecosystems, different species of organisms with the whole range of their variants and genes adapted to different climates, environments along with their interactions and processes (Shmida and Wilson, 1985). According to Dajoz (1985), the ecosystem diversity is due to diversity of niches, trophic levels and ecological processes like nutrient cycling, food webs, energy flow, role of dominant species and various related biotic interactions. Such type of diversity can generate more productive and stable ecosystems or communities able to tolerate various types of stresses such as drought (Bergonzini, 2004). Biodiversity is very 
essential for natural pest control, maintenance of population of various species, pollination by insects and birds, nutrient cycling, conservation and purification of water, and soil formation (Dajoz, 1985). Tropical rain forest is a luxuriant forest composed of broad-leaved trees that form a dense upper canopy and contain a diverse array of vegetation (Gay, 1993). It is found in wet tropical uplands and lowlands around the Equator and usually characterized by a combination of high species diversity, density and productivity (Whitmore, 1984; Choula et al., 2013).

The implementation of development projects such as agriculture, infrastructure construction, mining and forestry exploration leads to land degradation, nutrient load loss and destruction of forest cover (Zapfack et al., 2013; Bonansoa et al., 2016; Ndema Nsombo et al., 2016). These anthropogenic factors are at the beginning of vegetation succession which leads to the creation of a new forest in balance or climax state. One aspect of forest degradation is excavation carried out during the implementation of various projects (i.e. mines and parks) or logging. These areas, once abandoned by man, can be re-colonized by natural succession of vegetation. But for some, there are barriers to the establishment of these successions, such as the insufficient amount of recruitment of vegetative propagules (roots and branches), seeds entering the site, seeds and seedling predation, the absence of a micro-habitat for seed germination and seedling establishment, lack of nutrients in the soil, periodic droughts and competition among herbs (Duncan and Chapman, 1999; Holl, 1999; Guariguata and Ostertag, 2000; Slocum et al., 2004). It has been demonstrated that some successions result in formation of forests in which a particular species is relatively abundant (Bourland et al., 2015). Factors that might influence succession and species diversity include rainfall, temperature and soil chemical properties (Fonge et al., 2011). Succession also depends on the substrate such as on excavated land, sand and lava deposits. The duration of forest succession which takes over a hundred years could be reduced by forestry.

Planting trees is recognized as an effective way to counteract barriers that prevent the vegetation succession process. It changes the physical and biological conditions of the site such as light, temperature and humidity at the soil surface to promote germination; creating shelter to attract wildlife that brings seeds; fertilizes the soil by falling leaves and protects against erosion (Parrota et al., 1997; Aide et al., 2000; Chazdon, 2003). Bailly et al. (1979) describes the forest as the most efficient plant arrangement for the protection of land, with its action exerted through several factors such as the development of the root system that increases soil porosity, the presence of canopies that form an evaporation surface at a certain height, the litter which acts as a sponge that increases retention capacity and promotes the infiltration of water. In addition to the challenges of rapidly restoring forest cover, the choice of planted woody species takes into account several criteria such as the conservation of endangered forest species like Millettia laurentii which due to over-exploitation, is currently under conservation measures taken by the state of Cameroon. Despite the fact that it is not in its natural environment, it could adapt to this type of forestry just like a local (Microberlinia bisulcata) or pioneer (Lophira alata) tree species (Newbery et al., 1998; Lemmens et al., 2008). A variety of soil nutrients must be present in available form for seedlings to be successful. Elements such as carbon, nitrogen $(\mathrm{N})$ and hydrogen usually cycle through the organic material present in the forest, while potassium $(\mathrm{K})$ and phosphorus (P) come from the mineral portion of the soil (Ward and Worthley, 2003). Seedlings also require a variety of minor nutrients such as copper, iron and zinc (Nouck et al., 2016). Moreover, inorganic fertilization can influence soil fertility, regeneration and 
growth of these species on degraded sites in tropical rainforests. Developing soil fertility management options for increased productivity of woody species must be a challenge in most parts of sub-Saharan Africa, where soils are constrained by $\mathrm{N}$ and $\mathrm{P}$ deficiencies (Abdel-Motagally et al., 2009; Jemo et al., 2010). Adequate supply of inorganic-N fertilizer is beneficial for carbohydrates and protein metabolism, promoting cell division and cell enlargement (Shehu et al., 2010). Similarly, good supply of inorganic-P fertilizer is usually associated with increased root density and proliferation which aid in extensive exploration and supply of nutrients and water to the growing plant parts, resulting in increased growth and yield traits (Maiti and Jana, 1985). Due to the vital role that $\mathrm{K}$ plays in plant growth and metabolism, K-deficient plants show a very general phenotype, which is characterized by reduced growth, photosynthesis and impaired osmoregulation and transpiration (Amtmann et al., 2006). Nutrients exported from the soil through harvested biomass or loss from soil by gaseous loss, leaching, or erosion must be replaced with nutrients from external sources. The judicious use of chemical fertilizer is also essential to maintain soil fertility (Hossner and Juo, 1999). There is little knowledge available on the impact of the chemical fertilizers on the growth characteristics and regeneration rate of the woody species on degraded soil of the tropical rainforest for efficient utilization.

Therefore, this study was undertaken to evaluate the impact of inorganic fertilization sources on growth, nutrient uptake and regeneration rate of $M$. laurentii, M. bisulcata and L. alata plants on degraded tropical rainforest land. We hypothesized that inorganic fertilization sources $(\mathrm{N}, \mathrm{P}$ and $\mathrm{K})$, single or in combination, can act as efficient fertilizers that will lead to increased plant growth, nutrient uptake and regeneration rate of woody species on degraded tropical rainforest land. A comparative study of the use of these three woody species as catalysts for reforestation in degraded tropical rainforest was also discussed.

\section{Materials and methods}

\section{Study area and soil sampling}

The SIPO I site located at the South West region of Cameroon covers approximately $30000 \mathrm{~km}^{2}$ and lies between $9^{\circ} 00^{\prime} 09^{\prime \prime}-9^{\circ} 00^{\prime} 13^{\prime \prime} \mathrm{E}$ long. and $4^{\circ} 24^{\prime} 40^{\prime \prime}-4^{\circ} 24^{\prime} 45^{\prime \prime} \mathrm{N}$ lat. (Fig. 1). This site was completely cleared of forest cover during oil exploration operations and the soil was excavated about ten meters deep. The climate of SIPO I is characterized by abundant rainfall with average annual rainfall of $3470 \mathrm{~mm}$ and average temperature of $26.1^{\circ} \mathrm{C}$. Soils are from sedimentary rocks and are highly acid and eroded (Fig. 2, Table 1). The horizons of the basement are usually red or yellow, indicating accumulation of free iron oxides. These ultisols are formed on old land surfaces covered by forest vegetation. The physical and chemical characteristics of the soil taken from the excavated land and unaltered land (control sample) are shown in Table 1.

Table 1. Mean values of soil sample constituents from the SIPO I site

\begin{tabular}{|c|c|c|c|c|}
\hline \multirow[t]{2}{*}{ Soil properties } & \multicolumn{2}{|c|}{ Experimental site } & \multicolumn{2}{|l|}{ Control } \\
\hline & $0-30 \mathrm{~cm}$ & $30-60 \mathrm{~cm}$ & $0-30 \mathrm{~cm}$ & $30-60 \mathrm{~cm}$ \\
\hline Particles & & & & \\
\hline Clay \% & $20.6 \mathrm{~d}$ & $21.9 \mathrm{~d}$ & $19.0 \mathrm{~d}$ & $18.7 d$ \\
\hline Limon $\%$ & $9.3 \mathrm{e}$ & $10.0 \mathrm{e}$ & $3.9 \mathrm{ef}$ & $4.3 \mathrm{ef}$ \\
\hline Sand $\%$ & $70.1 \mathrm{~b}$ & $68.1 \mathrm{~b}$ & $77.1 \mathrm{a}$ & $77.0 \mathrm{a}$ \\
\hline
\end{tabular}




\begin{tabular}{llllc}
\hline Organic carbon $\%$ & $0.8 \mathrm{~g}$ & $0.6 \mathrm{~g}$ & $2.4 \mathrm{f}$ & $1.9 \mathrm{f}$ \\
Total N & $0.01 \mathrm{i}$ & $0.01 \mathrm{i}$ & $0.3 \mathrm{~h}$ & $0.1 \mathrm{~h}$ \\
$\mathrm{C} / \mathrm{N}$ & $80 \mathrm{a}$ & $60 \mathrm{c}$ & $80 \mathrm{e}$ & $19.0 \mathrm{~d}$ \\
Available P, $\mathrm{mg} / \mathrm{kg}$ & $14.0 \mathrm{de}$ & $12.70 \mathrm{de}$ & $6.5 \mathrm{e}$ & $5.0 \mathrm{e}$ \\
$\mathrm{Al}+\mathrm{H}(\mathrm{cmol} / \mathrm{kg})$ & $4.7 \mathrm{ef}$ & $4.8 \mathrm{ef}$ & $1.9 \mathrm{f}$ & $2.5 \mathrm{f}$ \\
\hline Acidity & & & & \\
$\mathrm{pH}\left(\mathrm{H}_{2} \mathrm{O}\right) 1: 2.5$ & $4.5 \mathrm{f}$ & $4.6 \mathrm{f}$ & $4.1 \mathrm{f}$ & $4.1 \mathrm{f}$ \\
$\mathrm{pH}(\mathrm{KCl}) \quad 1: 2.5$ & $3.8 \mathrm{f}$ & $3.8 \mathrm{f}$ & $3.1 \mathrm{f}$ & $3.3 \mathrm{f}$ \\
Exchangeable bases $(\mathrm{mg} / \mathrm{kg})$ & & & & \\
$\mathrm{Ca}^{2+}$ & $4.2 \mathrm{f}$ & $5.1 \mathrm{f}$ & $2.9 \mathrm{f}$ & $4.2 \mathrm{f}$ \\
$\mathrm{Mg}^{2+}$ & $3.2 \mathrm{f}$ & $3.1 \mathrm{f}$ & $3.0 \mathrm{f}$ & $3.1 \mathrm{f}$ \\
$\mathrm{K}^{+}$ & $0.2 \mathrm{~h}$ & $0.2 \mathrm{~h}$ & $0.2 \mathrm{~h}$ & $0.1 \mathrm{~h}$ \\
$\mathrm{Na}^{+}$ & $0.1 \mathrm{~h}$ & $0.1 \mathrm{~h}$ & $0.1 \mathrm{~h}$ & $0 \mathrm{~h}$ \\
Total bases & $7.7 \mathrm{e}$ & $8.5 \mathrm{e}$ & $6.2 \mathrm{e}$ & $7.4 \mathrm{e}$ \\
$\mathrm{CEC}$ & $7.8 \mathrm{e}$ & $6.9 \mathrm{e}$ & $15.4 \mathrm{~d}$ & $11.7 \mathrm{de}$ \\
\hline
\end{tabular}

Data represent mean $\pm \mathrm{SD}(\mathrm{n}=5)$; within rows, means followed by the same letter are not significantly different $(\mathrm{p}<0.05)$ by Fisher LSD test. CEC: Cation Exchange Capacity

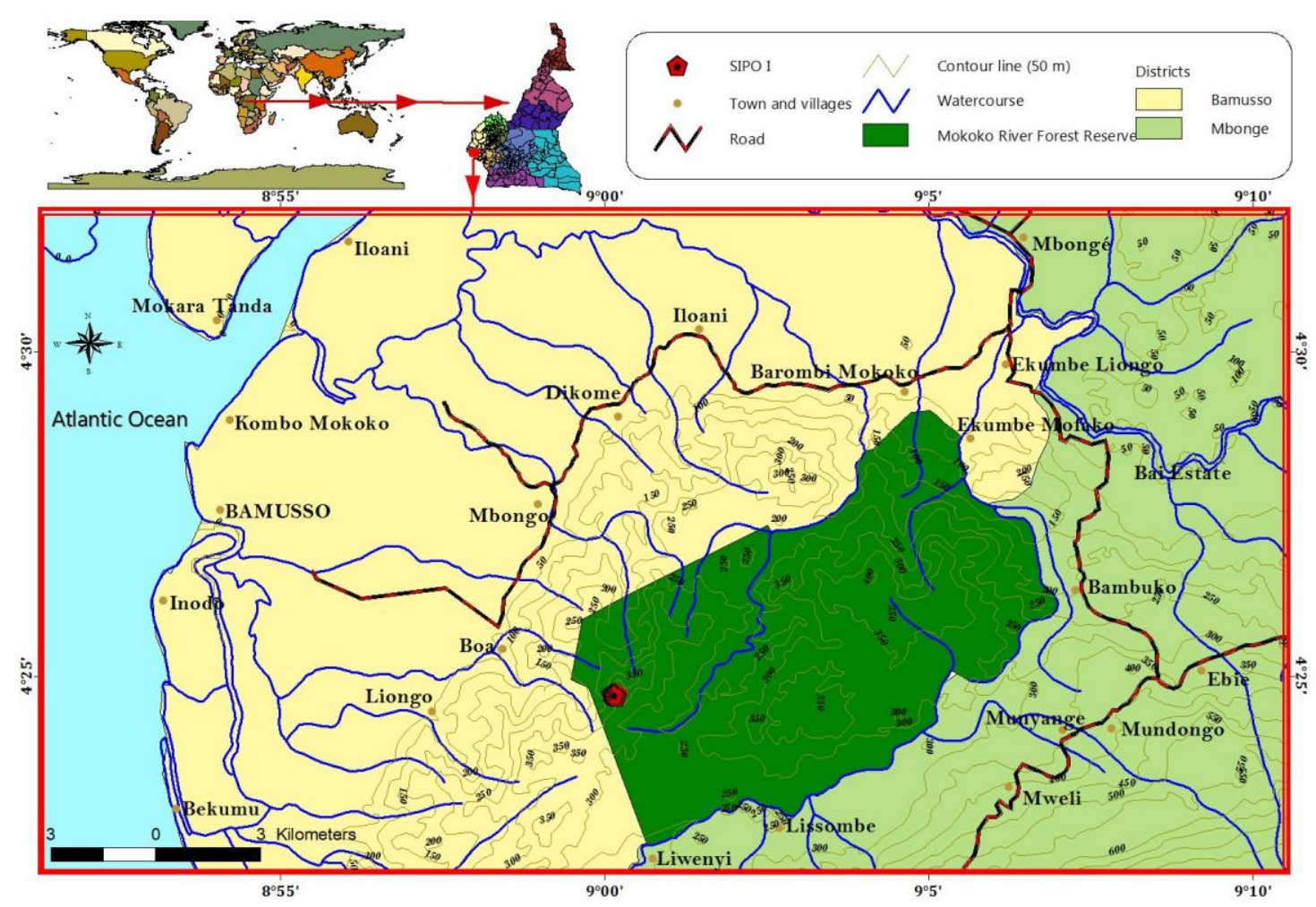

Figure 1. Location of the SIPO I site in the Mokoko River forest reserve

\section{Plant material}

Millettia laurentii De Wild is a leguminous tree from Africa and native to the Democratic Republic of Congo, Cameroon, Gabon and Equatorial Guinea. It is listed as endangered in the International Union for Conservation of Nature (IUCN) Red List, principally due to destruction of its habitat and over-exploitation for timber. Microberlinia bisulcata A. Chev. is also a leguminous species found only in southwestern Cameroon and its natural habitat is subtropical or tropical dry 
forests (Cheek and Cable, 2000). It is also listed as endangered in the IUCN Red List of Threatened Species. This valuable timber species occurs in lowland rainforest areas, usualy on sandy soils in flat areas. Large-scale habitat decline due to clearance for agriculture and exploitation have caused population declines. Lophira alata Banks ex Gaertn. is a species of plant in the Ochnaceae family. Its natural habitat is tropical moist lowland forests. The timber is extremely hard and used for railroad ties, electric fences and bridge planking. L. Alata needs full sunlight to grow, seedlings can persist for some time in the shady undergrowth and resume growth if breaks in the canopy occur (Biwolé et al., 2012). The seeds of $M$. Laurentii were collected from Mvengue and Mvangan in South Cameroon while those of L. alata were originating from the South Bakundo forest. The seedlings of $M$. bisulcata were harvested in the nearby forest.
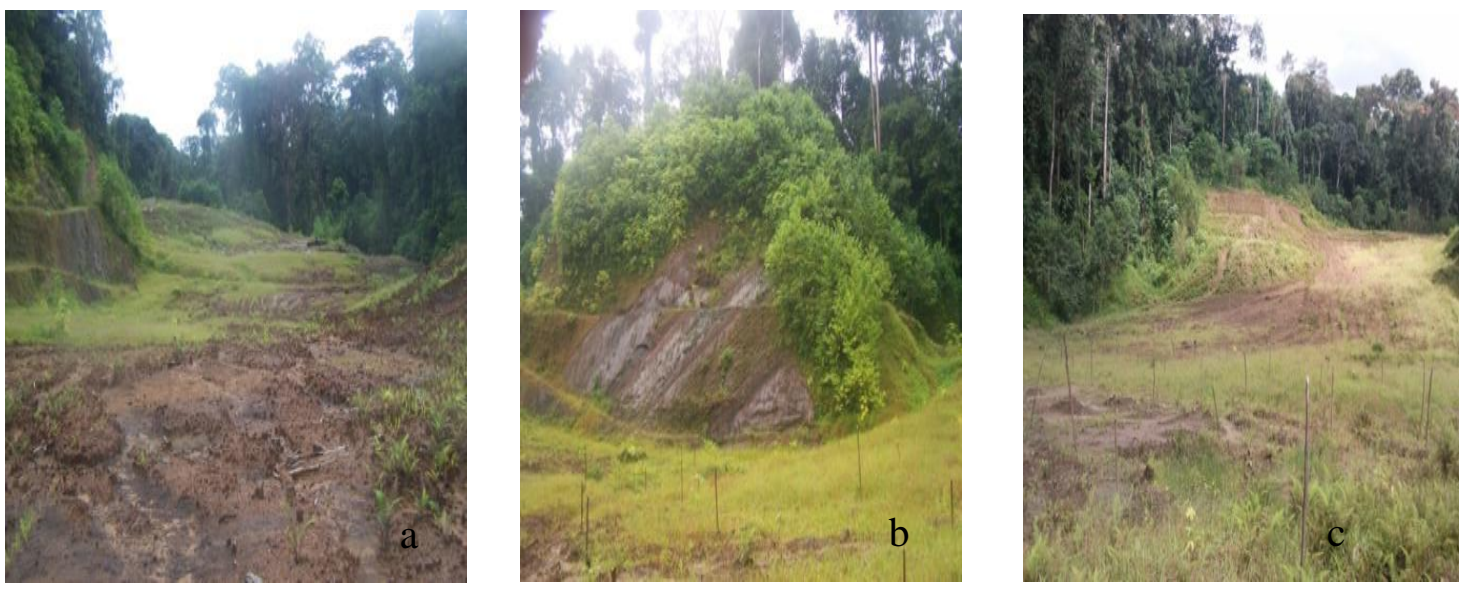

Figure 2. View of SIPO I showing traces of erosion on the cleared area (a), cleared/ excavated hill (b) and platform (c)

\section{Methods}

\section{Experimental design}

The experiment was performed in a randomized complete block design with six replicates. Three fertilizer applications (urea, single superphosphate and muriate of potash) were used on plots each measuring $30 \times 30 \mathrm{~m}$. A plot with no fertilizer additions was taken as control. Thirty plots were established to cover the entire area. Each plot consisted of 5 plant rows and 5 columns spaced $4 \times 4 \mathrm{~m}$. Each plant was identified with a code (Fig. 3) consisting of the name of the plot, the line number and column number. One of the three species was planted on the first three columns of each plot and all three species were planted on the last two. The different fertilizers selected for the experiment were applied in each case around the plant ( $3 \mathrm{~g} / \mathrm{plant}) 123$ days after planting (DAP). Inorganic-N fertilizer was applied as urea $(46 \% \mathrm{~N})$, Inorganic-P as single superphosphate $(33.5 \% \mathrm{P})$ and Inorganic-K as muriate of potash $(49.8 \% \mathrm{~K})$, singly or in combination (Wamba et al., 2012). 


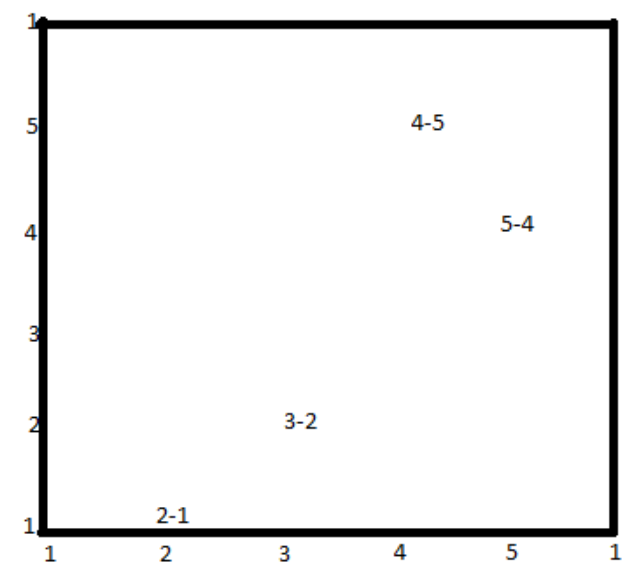

Figure 3. Codification of plants on the experimental plots.

\section{Field and laboratory data collection}

Stem diameter (SD), shoot length (SL), number of leaves (NL) and number of branches (NB) were recorded at 123, and 331 DAP. Leaves, stems and roots were separately dried at $62{ }^{\circ} \mathrm{C}$ for $72 \mathrm{~h}$ and their dry weights determined (Taffouo et al., 2010). Leaf Powders were analyzed for total phosphorus $(\mathrm{P})$, total nitrogen $(\mathrm{N})$, calcium $(\mathrm{Ca})$, potassium $(\mathrm{K})$ and magnesium $(\mathrm{Mg})$ in laboratory according to the methods described by Taffouo et al. (2010).

\section{Regeneration rate of plants}

The regeneration rate $(\mu)$ of plants was calculated as in the following equation:

$$
\mu=\text { NL/NT x } 100
$$

where NL represents the number of live plants and NT the total number of plants in plots.

\section{Soil analysis}

Five composite samples prepared from 0-30 and 30-60 $\mathrm{cm}$ depths within plots were analyzed in the laboratory of the Institute of Agricultural Research for Development (IRAD), Cameroon. The parameters analyzed included (i) particle size distribution by the method of Davidson (1955), (ii) organic carbon measured by the procedure of Walkley and Black (1934), (iii) exchangeable $\mathrm{Ca}$ and $\mathrm{Mg}$ of the soil using the procedure of Jackson (1958), (iv) total N content by the method of Kjeldahl (AOAC, 1980), (v) available $\mathrm{P}$ by the method of proportioning colorimetric starting from the nitrochlorhydric solution of ashes (Stuffins, 1967), (vi) soil $\mathrm{pH}$ measured by the procedure of Nanganoa et al. (2013), and (vii) K content determined using flame photometer (Jenway) (Prevel et al., 1984).

\section{Statistical analyses}

All data were statistically analyzed using Statistica (version 9, Tulsa, OK, USA). They were first subjected to analyses of variance (ANOVA). Statistical differences between treatment means were established using the Fisher LSD test at $p<0.05$. Two- 
way ANOVA was used to estimate whether species, nutrient fertilization sources, singly or in interaction had a significant influence on the measured parameters.

\section{Results}

\section{Regeneration of seedlings}

The regeneration rate of seedlings was estimated by evaluating the number of live plants 123 and 331 days after planting (DAP) (Figs. 4 and 5 ). A significant difference between species was observed for the behavior of seedlings 123 DAP (Fig. 4). M. laurentii and L. alata showed significantly $(\mathrm{p}<0.05)$ higher number of live plants (82.40 and $84.80 \%$ respectively) than those of $M$. Bisulcata $(46.40 \%)$.

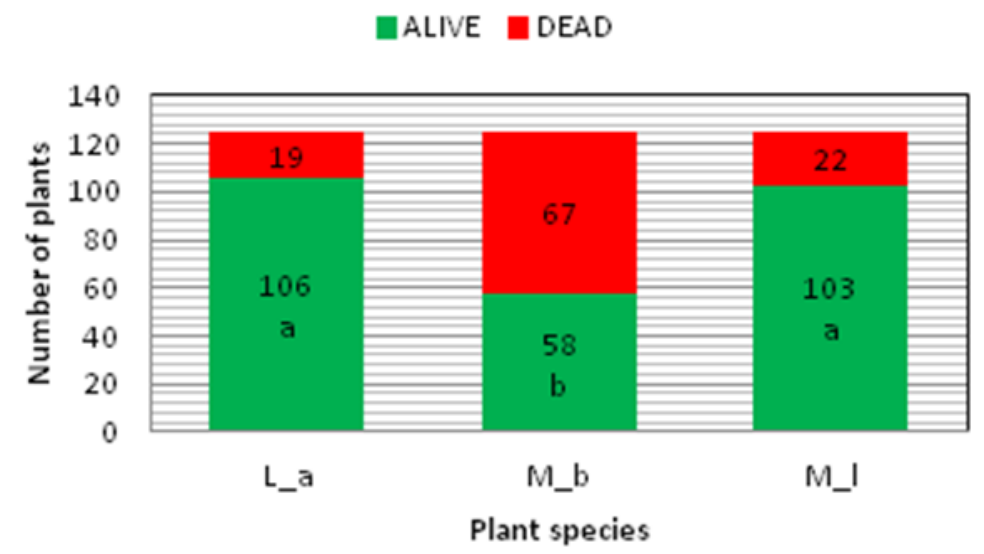

Figure 4. Number of live plants 123 days after planting (M_b : Microberlinia bisulcata A. Chev. ; L_a : Lophira alata Banks ex Gaertn. ; M_l: Millettia laurentii De Wild). The letters ( $a$, b) indicate significant differences between plant species using Fisher test ( $p<0.05$ ).

Under field conditions, inorganic-N, $\mathrm{P}$ or $\mathrm{K}$ fertilizer sources supplied singly or in combination had significant effects on regeneration rate (Fig. 5). Application of N, P or $\mathrm{K}$ fertilizers in combination led to a significant $(\mathrm{p}<0.05)$ increase of number of live plants in all woody species compared to untreated plants (Fig. 5A, B and C). Number of live plants was negatively affected by $\mathrm{P}$ supply in all plant species (Fig. 5A, $B$ and $C$ ). $M$. bisulcata had relatively higher number of live plants under NPK fertilization than $L$. alata and $M$. laurentii as compared to the plants fed with $\mathrm{K}, \mathrm{N}$ or P singly and untreated controls (Fig. 5A, B and C). However, L. alata and M. laurentii showed higher number of live plants than $M$. bisulcata when plants were enriched only with $\mathrm{N}$ fertilizer (Fig. $5 A, B$ and $C$ ).

\section{Growth characteristics}

Plant growth was estimated by measuring the stem diameter (SD), shoot length (SL), number of leaves (NL) and branches (NB) 331 DAP (Table 2). This study showed a significant increase $(\mathrm{p}<0.05)$ of SD, SL and NL in $M$. laurentii under inorganic fertilizer application compared to untreated control (Table 2). No significant differences were noted for SD, SL and NL in L. alata and M. bisulcata when inorganic-N, P or K fertilizers was applied singly or in combination, but only $\mathrm{N}$ fertilization had a negative influence in SL and NL of M. bisulcata (Table 2). N, P or K fertilizers applied singly 
and in combination did not influence NB in $M$. bisulcata and $M$. laurentii plants except for $\mathrm{K}$ fertilizer with a significant decrease observed compared to untreated plants (Table 2). A significant two-way interaction between the factors 'nutrient fertilization sources' and species was observed for SL and NL (Table 2). In M. laurentii, the plants supplied with $\mathrm{N}, \mathrm{P}$ or $\mathrm{K}$ fertilizers singly or in combination showed significantly $(\mathrm{p}<0.05)$ higher SD, SL, NL and NB compared to L. alata and M. bisulcata plants 331DAP (Table 2).

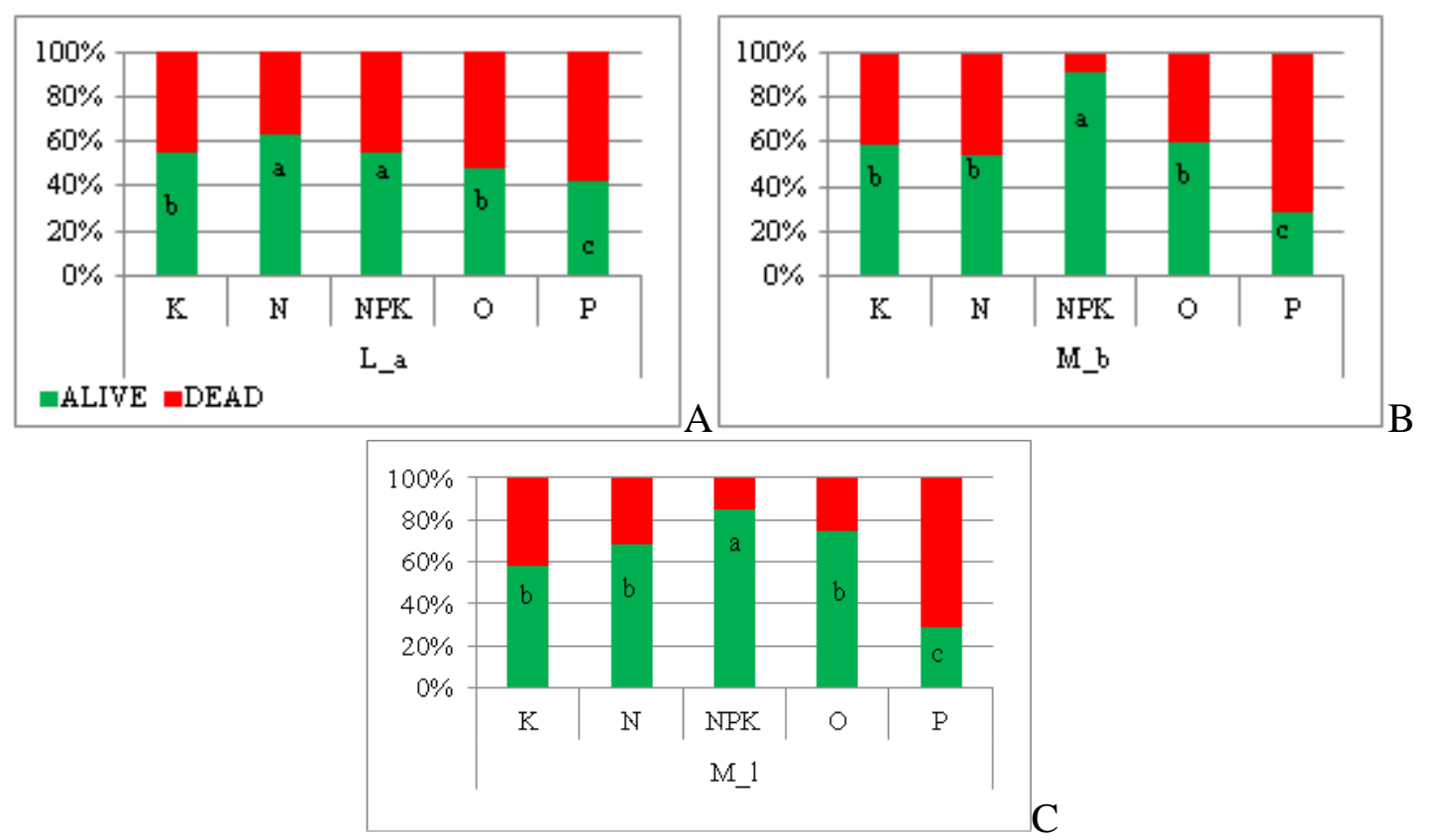

Figure 5. Number of live and dead plants (\%) 331days after planting under different fertilizer treatments. A : L_a : Lophira alata Banks ex Gaertn. ; B : M_b : Microberlinia bisulcata A.

Chev. ; $C: M \_l:$ Millettia laurentii De Wild $N: N 46 \% ; K: K_{2} O 49.8 \%$; NPK : NPK 20- 10$10 \% ; \mathrm{P}: \mathrm{P}_{2} \mathrm{O}_{5} 33.5 \%$ and $\mathrm{O}:$ Control treatment. The letters $(a, b)$ indicate significant differences between treatments using Fisher test $(p<0.05)$.

\section{Nutrient partitioning}

The nutrient contents in leaves, stems and roots of L. Alata, M. bisulcata and M. laurentii were affected by different inorganic fertilizer sources (Table 3). Application of inorganic-N, $\mathrm{P}$ or $\mathrm{K}$ fertilizers singly or in combination had a positive effect on leaf $\mathrm{N}$ concentrations in all three woody species (Table 3). Leaf $\mathrm{K}$ content was positively influenced by different inorganic fertilizer sources in M. Laurentii (Table 3). $M$. Laurentii plants supplied with N, P, and NPK fertilizers showed significantly $(\mathrm{p}<0.05)$ higher leaf $\mathrm{N}, \mathrm{P}, \mathrm{Ca}$ and $\mathrm{K}$ concentrations, respectively than those of L. Alata and $M$. bisulcata. Application of inorganic-N, $\mathrm{P}$ or $\mathrm{K}$ fertilizers singly or in combination on the contrary, decreased leaf $\mathrm{Mg}$ concentration in L. Alata, stem $\mathrm{N}$ concentration in $M$. Bisulcata and root Ca concentrations in M. Laurentii plants (Table 3). Application of inorganic-P fertilizer enhanced leaf $\mathrm{Mg}$ concentration significantly $(\mathrm{p}<0.05)$ in $M$. Laurentii plants compared to untreated control (Table 3). Under inorganic fertilizer application, the leaves of all three species showed significantly $(\mathrm{p}<0.05)$ higher amount of $\mathrm{N}, \mathrm{P}, \mathrm{K}, \mathrm{Ca}$ and $\mathrm{Mg}$ than those of stems and roots except for stem $\mathrm{Ca}$ and $\mathrm{Mg}$ in $L$. 
Alata plants. A significant two-way interaction between the factors 'species' and 'inorganic fertilizer sources' was observed for $\mathrm{N}$ and $\mathrm{Mg}$ concentrations (Table 3).

Table 2. Mean values of growth parameters in woody species at the vegetative stage (331 $D A P)$ under inorganic fertilizer applications

\begin{tabular}{|c|c|c|c|c|c|}
\hline \multirow[b]{2}{*}{ Species } & \multirow[b]{2}{*}{$\begin{array}{l}\text { Inorganic fertilizer } \\
\text { (g/plant) }\end{array}$} & \multicolumn{4}{|c|}{ Plant growth parameters } \\
\hline & & $\begin{array}{l}\text { Stem diameter } \\
(\mathrm{mm})\end{array}$ & $\begin{array}{l}\text { Shoot length } \\
\text { (cm) }\end{array}$ & No. of Leaves & $\begin{array}{c}\text { No. of } \\
\text { branches }\end{array}$ \\
\hline \multirow{5}{*}{ L. alata } & control & $4.29 \pm 1.16 \mathrm{c}$ & $22.07 \pm 3.15 f$ & $5.43 \pm 0.80 \mathrm{e}$ & - \\
\hline & NPK & $5.31 \pm 0.98 c$ & $21.00 \pm 2.55 \mathrm{f}$ & $7.19 \pm 0.91 \mathrm{~d}$ & - \\
\hline & $\mathrm{N}$ & $4.50 \pm 0.91 \mathrm{c}$ & $21.29 \pm 3.26 f$ & $5.50 \pm 0.50 \mathrm{e}$ & - \\
\hline & $\mathrm{P}$ & $4.25 \pm 1.16 \mathrm{c}$ & $19.50 \pm 5.32 \mathrm{f}$ & $4.25 \pm 0.42 \mathrm{e}$ & - \\
\hline & $\mathrm{K}$ & $4.10 \pm 0.83 \mathrm{c}$ & $18.00 \pm 3.85 \mathrm{f}$ & $4.30 \pm 0.68 \mathrm{e}$ & - \\
\hline \multirow{5}{*}{$\begin{array}{l}\text { M. } \\
\text { bisulcata }\end{array}$} & control & $10.63 \pm 2.62 \mathrm{a}$ & $43.67 \pm 3.00 \mathrm{~d}$ & $8.87 \pm 1.11 \mathrm{~d}$ & $2.33 \pm 0.47 \mathrm{~b}$ \\
\hline & NPK & $7.14 \pm 1.67 \mathrm{~b}$ & $45.76 \pm 3.46 \mathrm{~d}$ & $6.82 \pm 0.37 \mathrm{de}$ & $2.00 \pm 0.00 \mathrm{~b}$ \\
\hline & $\mathrm{N}$ & $8.18 \pm 1.89 \mathrm{ab}$ & $36.00 \pm 5.26 \mathrm{e}$ & $4.86 \pm 0.12 \mathrm{e}$ & $2.00 \pm 0.00 \mathrm{~b}$ \\
\hline & $\mathrm{P}$ & $10.57 \pm 3.89 \mathrm{a}$ & $53.05 \pm 3.41 \mathrm{c}$ & $9.89 \pm 1.40 \mathrm{~d}$ & - \\
\hline & $\mathrm{K}$ & $9.07 \pm 2.05 \mathrm{a}$ & $49.57 \pm 2.05 \mathrm{c}$ & $8.43 \pm 1.96 \mathrm{~d}$ & $1.00 \pm 0.00 \mathrm{c}$ \\
\hline \multirow{5}{*}{$\begin{array}{l}\text { M. } \\
\text { laurentii }\end{array}$} & control & $7.38 \pm 1.50 \mathrm{~b}$ & $44.23 \pm 2.28 \mathrm{~d}$ & $15.85 \pm 1.77 \mathrm{c}$ & $3.67 \pm 0.93 a$ \\
\hline & NPK & $8.93 \pm 2.43 \mathrm{ab}$ & $71.86 \pm 7.30 \mathrm{a}$ & $19.36 \pm 1.95 b$ & $3.67 \pm 0.63 \mathrm{a}$ \\
\hline & $\mathrm{N}$ & $9.17 \pm 1.71 \mathrm{a}$ & $60.74 \pm 6.31 \mathrm{~b}$ & $21.39 \pm 1.96 \mathrm{a}$ & $4.04 \pm 0.16 \mathrm{a}$ \\
\hline & $\mathrm{P}$ & $9.85 \pm 2.93 \mathrm{a}$ & $74,85 \pm 8.64 \mathrm{a}$ & $18.23 \pm 1.54 \mathrm{~b}$ & $2.92 \pm 0.54 \mathrm{ab}$ \\
\hline & $\mathrm{K}$ & $9.29 \pm 3.77 \mathrm{a}$ & $71,86 \pm 7.86 \mathrm{a}$ & $18.86 \pm 1.59 \mathrm{~b}$ & $2.29 \pm 0.45 b$ \\
\hline \multicolumn{6}{|c|}{ Two-way ANOVA results } \\
\hline \multicolumn{2}{|c|}{ Species (S) } & $* *$ & $* *$ & $* *$ & ns \\
\hline \multicolumn{2}{|c|}{ Fertilization sources $(\mathrm{F})$} & * & * & * & $\mathrm{ns}$ \\
\hline \multicolumn{2}{|c|}{ Interactions S X F } & ns & * & * & $\mathrm{ns}$ \\
\hline
\end{tabular}

Data represent mean \pm SD $(n=12)$; within columns, means followed by the same letter are not significantly different $(\mathrm{p}<0.05)$ by Fisher LSD test. The result of the two-way ANOVA analysis showing effects of inorganic fertilizer sources, species, and their interaction $(\mathrm{S} \times \mathrm{F})$ on the different plant growth parameters. ns not significant, ${ }^{*}$ Significant at $\mathrm{p}<0.05$,

$* *$ Significant at $\mathrm{p}<0.01$

Table 3. $\mathrm{N}, \mathrm{P}, \mathrm{Ca}, \mathrm{K}$ and $\mathrm{Mg}$ partitioning (mg/plant) of woody species grown under inorganic fertilization sources

\begin{tabular}{|c|c|c|c|c|c|c|c|}
\hline Species & & $\begin{array}{l}\text { Inorganic } \\
\text { fertilization } \\
\text { (g/plant) }\end{array}$ & $\mathbf{N}$ & $\mathbf{P}$ & $\mathbf{C a}$ & $\mathbf{K}$ & Mg \\
\hline \multirow{15}{*}{ L. alata } & \multirow{5}{*}{ Leaf } & Control & $13.3 \pm 0.5 \mathrm{c}$ & $1.6 \pm 0.4 \mathrm{~b}$ & $9.0 \pm 0.2 \mathrm{~d}$ & $10.6 \pm 0.1 \mathrm{bc}$ & $9.7 \pm 0.4 b$ \\
\hline & & NPK & $13.9 \pm 0.2 \mathrm{c}$ & $1.5 \pm 0.5 b$ & $4.4 \pm 0.1 \mathrm{f}$ & $9.3 \pm 0.2 b c$ & $1.5 \pm 0.2 \mathrm{c}$ \\
\hline & & $\mathrm{N}$ & $19.0 \pm 1.2 \mathrm{~b}$ & $1.9 \pm 0.2 \mathrm{~b}$ & $5.4 \pm 0.1 \mathrm{ef}$ & $11.0 \pm 0.3 \mathrm{~b}$ & $2.8 \pm 0.2 \mathrm{c}$ \\
\hline & & $\mathrm{P}$ & $12.7 \pm 1.0 \mathrm{c}$ & $1.5 \pm 0.2 \mathrm{~b}$ & $4.9 \pm 0.1 \mathrm{ef}$ & $7.4 \pm 0.2 \mathrm{c}$ & $3.2 \pm 0.2 \mathrm{c}$ \\
\hline & & $\mathrm{K}$ & $19.0 \pm 1.4 \mathrm{~b}$ & $1.9 \pm 0.4 \mathrm{~b}$ & $4.6 \pm 0.1 \mathrm{f}$ & $8.5 \pm 0.2 \mathrm{c}$ & $1.3 \pm 0.3 \mathrm{c}$ \\
\hline & \multirow{5}{*}{ Stem } & Control & $3.0 \pm 0.2 \mathrm{e}$ & $0.6 \pm 0.0 \mathrm{~cd}$ & $3.4 \pm 0.4 \mathrm{f}$ & $5.5 \pm 0.4 \mathrm{~cd}$ & $1.1 \pm 0.0 \mathrm{c}$ \\
\hline & & NPK & $3.6 \pm 0.2 \mathrm{e}$ & $0.4 \pm 0.0 \mathrm{de}$ & $13.2 \pm 0.2 \mathrm{c}$ & $3.2 \pm 0.1 \mathrm{~d}$ & $12.5 \pm 1.1 \mathrm{a}$ \\
\hline & & $\mathrm{N}$ & $3.0 \pm 0.1 \mathrm{e}$ & $0.9 \pm 0.1 \mathrm{c}$ & $9.4 \pm 0.3 d$ & $8.2 \pm 0.7 \mathrm{c}$ & $11.4 \pm 1.2 \mathrm{a}$ \\
\hline & & $\mathrm{P}$ & $2.3 \pm 0.1 \mathrm{ef}$ & $1.0 \pm 0.2 \mathrm{c}$ & $17.3 \pm 1.7 b$ & $1.9 \pm 0.1 \mathrm{e}$ & $9.7 \pm 1.1 b$ \\
\hline & & $\mathrm{K}$ & $9.0 \pm 0.1 \mathrm{~d}$ & $1.4 \pm 0.1 b c$ & $13.4 \pm 1.3 \mathrm{c}$ & $4.7 \pm 0.1 \mathrm{~d}$ & $11.8 \pm 1.2 \mathrm{a}$ \\
\hline & \multirow{5}{*}{ Root } & Control & $4.0 \pm 0.1 \mathrm{e}$ & $0.3 \pm 0.0 \mathrm{de}$ & $12.5 \pm 0.4 \mathrm{c}$ & $2.1 \pm 0.2 \mathrm{~g}$ & $2.3 \pm 0.2 \mathrm{c}$ \\
\hline & & NPK & $2.7 \pm 0.2 \mathrm{ef}$ & $0.2 \pm 0.0 \mathrm{e}$ & $4.2 \pm 0.1 \mathrm{f}$ & $6.6 \pm 0.5 \mathrm{c}$ & $1.4 \pm 0.4 \mathrm{c}$ \\
\hline & & $\mathrm{N}$ & $4.0 \pm 0.4 \mathrm{e}$ & $0.3 \pm 0.0 \mathrm{de}$ & $6.2 \pm 0.3 \mathrm{e}$ & $6.8 \pm 0.6 \mathrm{c}$ & $1.3 \pm 0.2 \mathrm{c}$ \\
\hline & & $\mathrm{P}$ & $2.7 \pm 0.1 \mathrm{ef}$ & $0.4 \pm 0.0 \mathrm{de}$ & $10.5 \pm 0.7 \mathrm{c}$ & $6.7 \pm 0.5 c$ & $1.9 \pm 0.8 \mathrm{c}$ \\
\hline & & K & $5.6 \pm 0.5 \mathrm{de}$ & $1.0 \pm 0.1 \mathrm{c}$ & $8.9 \pm 0.5 \mathrm{de}$ & $6.1 \pm 0.6 \mathrm{c}$ & $1.8 \pm 0.1 \mathrm{c}$ \\
\hline
\end{tabular}




\begin{tabular}{|c|c|c|c|c|c|c|c|}
\hline Species & & $\begin{array}{l}\text { Inorganic } \\
\text { fertilization } \\
\text { (g/plant) }\end{array}$ & $\mathbf{N}$ & $\mathbf{P}$ & $\mathbf{C a}$ & $\mathbf{K}$ & Mg \\
\hline \multirow{15}{*}{$\begin{array}{l}\text { M. } \\
\text { bisulcata }\end{array}$} & \multirow{5}{*}{ Leaf } & Control & $1.7 \pm 0.1 \mathrm{f}$ & $0.3 \pm 0.0 \mathrm{de}$ & $10.4 \pm 0.1 \mathrm{c}$ & $6.4 \pm 0.1 \mathrm{c}$ & $2.6 \pm 0.1 \mathrm{c}$ \\
\hline & & NPK & $5.9 \pm 0.2 \mathrm{de}$ & $0.5 \pm 0.0 \mathrm{~d}$ & $8.1 \pm 0.5 \mathrm{de}$ & $5.6 \pm 0.9 \mathrm{~cd}$ & $2.0 \pm 01 \mathrm{c}$ \\
\hline & & $\mathrm{N}$ & $7.3 \pm 0.7 \mathrm{~d}$ & $0.7 \pm 0.0 \mathrm{~cd}$ & $1.3 \pm 0.8 \mathrm{~g}$ & $6.5 \pm 0.1 \mathrm{c}$ & $3.3 \pm 0.1 \mathrm{c}$ \\
\hline & & $\mathrm{P}$ & $4.2 \pm 0.6 \mathrm{e}$ & $1.2 \pm 0.2 \mathrm{c}$ & $16.9 \pm 2.1 b$ & $5.7 \pm 0.2 \mathrm{~cd}$ & $0.2 \pm 0.0 \mathrm{f}$ \\
\hline & & $\mathrm{K}$ & $5.1 \pm 0.3 \mathrm{de}$ & $0.8 \pm 0.1 \mathrm{c}$ & $11.4 \pm 0.9 \mathrm{c}$ & $4.4 \pm 0.1 d$ & $1.3 \pm 0.0 \mathrm{c}$ \\
\hline & \multirow{5}{*}{ Stem } & Control & $5.6 \pm 0.2 \mathrm{de}$ & $1.0 \pm 0.0 \mathrm{c}$ & $2.3 \pm 0.2 \mathrm{fg}$ & $3.8 \pm 0.1 \mathrm{~d}$ & $1.3 \pm 0.0 \mathrm{c}$ \\
\hline & & NPK & $0.8 \pm 0.1 \mathrm{f}$ & $1.9 \pm 0.1 b$ & $5.9 \pm 0.3 \mathrm{ef}$ & $8.1 \pm 0.5 c$ & $2.1 \pm 0.1 \mathrm{c}$ \\
\hline & & $\mathrm{N}$ & $1.1 \pm 0.1 \mathrm{f}$ & $1.2 \pm 0.3 \mathrm{c}$ & $3.7 \pm 0.7 \mathrm{f}$ & $5.6 \pm 0.1 \mathrm{~cd}$ & $1.0 \pm 0.0 \mathrm{c}$ \\
\hline & & $\mathrm{P}$ & $0.7 \pm 0.0 \mathrm{f}$ & $1.4 \pm 0.1 \mathrm{bc}$ & $4.4 \pm 0.3 f$ & $6.6 \pm 0.2 \mathrm{c}$ & $1.4 \pm 0.1 \mathrm{c}$ \\
\hline & & $\mathrm{K}$ & $2.2 \pm 0.1 \mathrm{ef}$ & $1.6 \pm 0.1 b$ & $4.0 \pm 0.7 f$ & $6.7 \pm 0.3 c$ & $1.2 \pm 0.1 \mathrm{c}$ \\
\hline & \multirow{5}{*}{ Root } & Control & $3.8 \pm 0.5 \mathrm{e}$ & $0.8 \pm 0.1 \mathrm{c}$ & $3.4 \pm 0.5 f$ & $3.5 \pm 0.7 \mathrm{~d}$ & $1.3 \pm 0.1 \mathrm{c}$ \\
\hline & & NPK & $7.0 \pm 0.6 \mathrm{~d}$ & $0.6 \pm 0.1 \mathrm{~cd}$ & $7.4 \pm 0.5 \mathrm{e}$ & $4.1 \pm 0.1 \mathrm{~d}$ & $1.5 \pm 0.3 c$ \\
\hline & & $\mathrm{N}$ & $3.9 \pm 0.2 \mathrm{e}$ & $0.3 \pm 0.0 \mathrm{de}$ & $3.1 \pm 0.3 \mathrm{f}$ & $4.4 \pm 0.3 \mathrm{~d}$ & $1.6 \pm 07 \mathrm{c}$ \\
\hline & & $\mathrm{P}$ & $5.7 \pm 0.2 \mathrm{de}$ & $0.7 \pm 0.1 \mathrm{~cd}$ & $2.8 \pm 0.4 \mathrm{f}$ & $4.2 \pm 0.1 \mathrm{~d}$ & $1.3 \pm 0.4 \mathrm{c}$ \\
\hline & & $\mathrm{K}$ & $11.3 \pm 1.2 \mathrm{c}$ & $0.7 \pm 0.1 \mathrm{~cd}$ & $2.6 \pm 0.5 f$ & $4.9 \pm 0.2 \mathrm{~d}$ & $1.1 \pm 0.3 c$ \\
\hline \multirow{15}{*}{$\begin{array}{l}\text { M. } \\
\text { laurentii }\end{array}$} & \multirow{5}{*}{ Leaf } & Control & $14.0 \pm 1.8 \mathrm{c}$ & $1.2 \pm 0.1 \mathrm{c}$ & $11.7 \pm 0.6 \mathrm{c}$ & $13.8 \pm 0.2 b$ & $2.3 \pm 0.4 \mathrm{c}$ \\
\hline & & NPK & $20.6 \pm 1.2 b$ & $1.4 \pm 0.0 \mathrm{bc}$ & $18.4 \pm 0.4 \mathrm{a}$ & $17.1 \pm 0.3 \mathrm{a}$ & $3.8 \pm 0.8 \mathrm{c}$ \\
\hline & & $\mathrm{N}$ & $26.6 \pm 0.8 \mathrm{a}$ & $1.7 \pm 0.1 \mathrm{~b}$ & $10.2 \pm 0.5 \mathrm{c}$ & $16.3 \pm 0.6 \mathrm{a}$ & $2.9 \pm 0.5 c$ \\
\hline & & $\mathrm{P}$ & $24.8 \pm 0.7 \mathrm{a}$ & $2.9 \pm 0.1 \mathrm{a}$ & $16.0 \pm 0.7 \mathrm{ab}$ & $15.9 \pm 0.6 \mathrm{a}$ & $8.9 \pm 0.9 b$ \\
\hline & & $\mathrm{K}$ & $26.8 \pm 1.9 a$ & $1.5 \pm 0.0 \mathrm{c}$ & $12.9 \pm 0.2 \mathrm{c}$ & $16.0 \pm 0.7 \mathrm{a}$ & $3.2 \pm 0.5 \mathrm{c}$ \\
\hline & \multirow{5}{*}{ Stem } & Control & $1.0 \pm 0.0 \mathrm{~g}$ & $0.5 \pm 0.0 \mathrm{~d}$ & $15.2 \pm 0.4 \mathrm{~b}$ & $6.6 \pm 0.1 \mathrm{c}$ & $1.9 \pm 0.1 \mathrm{c}$ \\
\hline & & NPK & $11.5 \pm 0.2 \mathrm{c}$ & $0.6 \pm 0.1 \mathrm{~d}$ & $14.6 \pm 0.6 b c$ & $11.0 \pm 0.6 b$ & $1.9 \pm 0.1 \mathrm{c}$ \\
\hline & & $\mathrm{N}$ & $6.2 \pm 0.2 \mathrm{~d}$ & $0.3 \pm 0.0 \mathrm{de}$ & $15.4 \pm 0.7 \mathrm{~b}$ & $11.3 \pm 0.5 b$ & $2.7 \pm 0.0 \mathrm{c}$ \\
\hline & & $\mathrm{P}$ & $7.1 \pm 0.3 \mathrm{e}$ & $0.3 \pm 0.0 \mathrm{de}$ & $17.5 \pm 0.8 \mathrm{a}$ & $13.5 \pm 0.4 b$ & $2.3 \pm 0.0 \mathrm{c}$ \\
\hline & & $\mathrm{K}$ & $10.1 \pm 0.1 \mathrm{~cd}$ & $0.9 \pm 0.1 \mathrm{c}$ & $17.6 \pm 0.9 \mathrm{a}$ & $9.1 \pm 0.6 b c$ & $2.6 \pm 0.1 \mathrm{c}$ \\
\hline & \multirow{5}{*}{ Root } & Control & $1.5 \pm 0.3 \mathrm{f}$ & $0.3 \pm 0.0 \mathrm{de}$ & $13.5 \pm 0.5 \mathrm{c}$ & $5.0 \pm 0.1 \mathrm{~cd}$ & $1.1 \pm 0.0 \mathrm{c}$ \\
\hline & & NPK & $1.4 \pm 0.1 \mathrm{f}$ & $0.3 \pm 0.0 \mathrm{de}$ & $6.3 \pm 0.5 \mathrm{~d}$ & $7.8 \pm 0.3 c$ & $1.9 \pm 0.0 \mathrm{c}$ \\
\hline & & $\mathrm{N}$ & $1.4 \pm 0.1 \mathrm{f}$ & $0.2 \pm 0.0 \mathrm{e}$ & $8.5 \pm 0.4 \mathrm{~cd}$ & $6.5 \pm 0.1 \mathrm{c}$ & $2.3 \pm 0.1 \mathrm{c}$ \\
\hline & & $\mathrm{P}$ & $3.2 \pm 0.3 \mathrm{e}$ & $0.2 \pm 0.0 \mathrm{e}$ & $5.6 \pm 0.4 \mathrm{e}$ & $4.0 \pm 0.2 \mathrm{~d}$ & $0.7 \pm 0.0 \mathrm{~d}$ \\
\hline & & $\mathrm{K}$ & $1.5 \pm 0.0 \mathrm{f}$ & $0.4 \pm 0.0 \mathrm{de}$ & $7.8 \pm 0.7 \mathrm{~d}$ & $5.5 \pm 0.2 \mathrm{~cd}$ & $1.9 \pm 0.1 \mathrm{c}$ \\
\hline
\end{tabular}

Two way ANOVA results

Species (S)

Fertilization sources $(\mathrm{F})$

Interaction $\mathrm{S} \times \mathrm{F}$

$\begin{array}{lllll}* & \mathrm{~ns} & * & \mathrm{~ns} & * \\ * * & \mathrm{~ns} & * & \mathrm{~ns} & * \\ * & \mathrm{~ns} & \mathrm{~ns} & \mathrm{~ns} & *\end{array}$

Data represent mean $\pm \mathrm{SD}(\mathrm{n}=5)$; within columns, means followed by the same letter are not significantly different $(\mathrm{p}<0.05)$ by Fisher LSD test. The result of the two-way ANOVA analysis showing effects of species, soil nutrient fertilization, and their interaction $(S \times F)$ on plant nutrient status ns not significant,*significant at $\mathrm{p}<0.05$, $* *$ significant at $\mathrm{p}<0.01$

\section{Discussion}

The restoration of degraded land in the SIPO I site of Boa forest can be catalyzed by forestry techniques which in addition, provide the conditions for regeneration of forest species, shortened vegetation succession and duration to reach colonization climax (Dajoz, 1985). M. laurentii and L. alata showed higher number of live plants than those of M. Bisulcata 123 DAP. These results suggested the adaptation of $M$. laurentii and $L$. alata to distinct combinations of light, moisture, and soil amendments of SIP0 I site. Similar results were also observed by Ward and Worthley (2003). The lower performance presented by $M$. Bisulcata at this vegetative stage (123 DAP) compared to those of pioneer species (M. laurentii and L. Alata) could be 
explained by some limiting factors: (1) top soils of forests are covered with litter which endows them with particular nutritive characteristics (Ibrahim et al., 2010); (2) degraded zones lost some soil characteristics during implementation of industrial and mining projects. In fact, in the SIPO I site where excavation was done, the structure ranges from sandy loam to loamy-sandy-clay with low values of CEC and total $\mathrm{N}$ at all depths, rendering it vulnerable to erosion. Erosion is accentuated by aggressiveness of rainfall on naked land (Roose and Sarrailh, 1990; Graf et al., 2003). The carbon content, total N and CEC are low compared to reference soil and values obtained by Taffouo et al. (2010), Sharma and Raghubanshi (2011), Wamba et al. (2012) and Fokom et al. (2013). The low mineral content of this soil is due to degradation of forest cover (Bonansea et al., 2016; Ndema Nsombo et al., 2016) and the top soil horizons which were absent after excavation (Duryea, 2000). On the contrary, M. bisulcata had relatively higher number of live plants under inorganic-NPK fertilizer than L. alata and M. laurentii as compared to the plants fed with $\mathrm{K}, \mathrm{N}$ or $\mathrm{P}$ fertilizers singly or in combination 331 DAP. Ouédraogo et al. (2014) and Fayolle et al. (2015), studying the regeneration of a pioneer species (Milicia excelsa) and a non-pioneer species (Pericopsis elata) found that a pioneer species presented significantly lower performance than a non-pioneer species when planted on forest clearings. These results could be explained by the fact that pioneer species might not require optimum environmental conditions to thrive. According to Duryea (2000), the main root of these plants was reduced during planting to avoid folding of the root system in the form of " $\mathrm{L}$ " or " $\mathrm{J}$ " which is one of the drawbacks of using seedlings for regeneration. Efficient sylvicultural operations on such soil requires selection of plant species that are capable of adapting to it. Otherwise, it is important to consider modification of the site's soil structure and fertility (Lamd, 1994; Ndema Nsombo et al., 2010).

Soil nutrients play a role in the life cycle of the tree and must be present for survival and successful growth. In short supply, one or more nutrients can be the limiting factor to the growth and development of trees or stands (Ward and Worthley, 2003). In the present study, application of inorganic- $\mathrm{N}, \mathrm{P}$ or $\mathrm{K}$ singly or in combination led to a significant increase in SL, SD, NL and NB in M. laurentii plants. Adequate supply of inorganic-N is beneficial for carbohydrates and protein metabolism, promoting cell division and cell enlargement (Shehu et al., 2010; Debere et al., 2014). Similarly, good supply of inorganic-P is usually associated with increased root density, soil porosity and proliferation which aid in extensive exploration and supply of nutrients and water to the growing plant parts, resulting in increased growth and yield traits (Bailly et al., 1979; Maiti and Jana, 1985). Due to the vital role that $\mathrm{K}$ plays in plant growth and metabolism, K-deficient plants show a very general phenotype, which is characterized by reduced growth, photosynthesis and impaired osmoregulation and transpiration (Amtmann et al., 2006). In this study, no significant differences were noted for SD, SL and NL in L. alata and M. bisulcata when inorganic-N, P or K was applied singly or in combination. The minimum amount of light required for optimum growth and development varies dramatically among tree species. According to Ward and Worthley (2003), species that compete best in full sunlight have the capacity for rapid height growth and are often found in the upper layers of the forest canopy while those that are capable to compete in the shade of other trees can occupy lower layers in the canopy, and each canopy layer will intercept additional sunlight. In $M$. laurentii, the plants supplied with inorganic-N, P or K fertilizers singly or in combination showed higher SD, SL, NL and NB compared to L. alata and M. bisulcata 331 DAP. Similar results 
have previously been documented by Ashton et al. (2001) who studied the rain forest in SouthWest Sri Lanka and suggested that the early formation of the branches and the large number of leaves allow trees (catalysts) to cover the site and to create a favorable microclimate for the growth of other forest species. The branches and leaves falling constitute litter which is important for the formation of the humus layer and prevention against erosion (Ibrahim et al., 2010).

The results of this study highlighted the importance of nutrients uptake and their distribution in plant parts of the three woody species. Application of inorganic-N, P or $\mathrm{K}$ fertilizers singly or in combination had a positive effect on leaf $\mathrm{N}$ concentrations in all the three woody species. Mineral uptake is largely influenced by the availability of soil mineral nutrients which in turn affects the chemical composition of the plants (Juma and Van Averbeke, 2005). Taffouo et al. (2014) reported that $\mathrm{N}$ is directly transferred from the roots towards the leaves of plants where the $\mathrm{N}$ compounds are used for protein biosynthesis. In this study, M. Laurentii (N fixing species) plants supplied with inorganic-N, P or K fertilizers singly or in combination showed higher leaf N, P, Ca and $\mathrm{K}$ concentrations than those of L. Alata and M. bisulcata. Ojiem et al. (2000) demonstrated that legumes have the potential to improve soil nutrients status through biological $\mathrm{N}$ fixation and incorporation of biomass into the soil as green manure. In cowpea, the $\mathrm{N}$ requirements for developing pods are not only covered by root uptake or biological $\mathrm{N}$ fixation, but also by mobilization of $\mathrm{N}$ in vegetative tissues (Douglas and Weaver, 1993). Some food and fodder legumes are known for $\mathrm{N}$ fixing ability; however their establishment with $\mathrm{P}$ fertilization enhances nodulation and hence fixation of atmospheric N (Masinde and Omolo, 2007). According to Jemo et al. (2010) and Taffouo et al. (2014), the process of foliar N mobilization is dependent on the amount of $\mathrm{P}$ uptake by plants. Under inorganic fertilization, the leaves of all the three woody species showed higher amounts of $\mathrm{N}, \mathrm{P}, \mathrm{K}, \mathrm{Ca}$ and $\mathrm{Mg}$ than those of stems and roots except for stem $\mathrm{Ca}$ and $\mathrm{Mg}$ in L. Alata plants. According to Amtmann et al. (2006), leaves are important to plants and trees because they convert sunlight energy to food through the process of photosynthesis. In this study, the highest accumulation of nutrients was recorded in $M$. Laurentii. In fact this species has been successfully tested for forestry by macro-cuttings (Nsielolo Kitoko et al., 2015). In the analysis combining regeneration rate, growth and nutrient partitioning of the parameters measured, the results revealed the best adaptation by $M$. laurentii to soil nutrient amendment. This species could be used as a catalyst for reforestation in degraded tropical rainforest land.

\section{Conclusions}

Restoration of degraded tropical rainforest land in the SIPO I site can be catalyzed by intervention of forestry and agronomic management techniques which provide the conditions for regeneration of forest species, shortened vegetation succession and duration to reach a state of balance of the forest (climax). M. laurentii and L. alata showed higher number of live plants ( 82.40 and $84.80 \%$ respectively) than those of M. Bisulcata $(46.40 \%)$ 123 DAP. The specific combination (NPK) was found as efficient fertilizer to enhance the woody species regeneration. The highest accumulation of $\mathrm{N}, \mathrm{P}, \mathrm{K}, \mathrm{Ca}$ and $\mathrm{Mg}$ concentrations was found in leaves compared to stems and roots of all the species.

In M. Laurentii plants, SD, SL, NL, NB and N, P, Ca and K uptake were positively influenced by inorganic-N, P, K or NPK fertilizer treatments compared to L. alata and M. Bisulcata 331 DAP. These results revealed the best adaptation by $M$. laurentii to soil 
nutrient amendment. Therefore, this woody species can be considered as catalyst for reforestation of degraded tropical rainforest land such as that encountered in the SIPO I site of Boa forest in Cameroon.

Based on these attributes $M$. laurentii which is subjected to over-exploitation is strongly recommend for reforestation in degraded tropical rainforest land.

Developing soil fertility management options for increasing productivity of woody species must be a challenge in most parts of sub-Saharan Africa, where soils are constrained by $\mathrm{N}$ and $\mathrm{P}$ deficiencies.

Acknowledgements. This work was supported by the Kosmos Energy LLC through Connect Green Industry Solution Sarl.

\section{REFERENCES}

[1] Abdel-Motagally, F.M.F., Attia, K.K. (2009): Response of sugar beet plants to nitrogen and potassium fertilization in sandy calcareous soil. - International Journal of Agriculture and Biodiversity 11(6): 695-700.

[2] Aide, T.M., Zimmerman, J.K., Pascarella, J.B., Rivera, L., Marcano-Vega, H. (2000): Forest regeneration in a chronosequence of tropical abandoned pasture : implication for restoration ecology. - Restoration Ecology 8(4): 328-338.

[3] Amtmann, A., Hammond, J.P., Armengaud, P., White, P.J. (2006): Nutrient sensing and signaling in plants: potassium and phosphorus. - Advances in Botanical Research 43: 209-257.

[4] AOAC. (1980): Official methods of analysis. Association of official analytical chemists. - William Horwitz ed., Washington DC.

[5] Ashton, M.S., Gunatilleke, C.V.S., Singhakumara, B.M.P., Gunatilleke, I.A.U.N. (2010): Restoration pathways for rain forest in southwest Sri Lanka: a review of concept and models. - Forest Ecology and Management 154: 409-430.

[6] Bailly, C., Goujon, P., Pare, J. (1979): Soil conservation in south of the Sahara. Tropical Forest Technical Center (TFTC). - Ministry of cooperation, Paris, France.

[7] Bailly, C., Malvos, C., Sarrailh, J.M., Rakotomana, L., Rampananana, L. (1976): Study of the sensibility of Madagascar soil to erosion. Experimentation in elementary plots. Wood and Forest of the Tropics 169: 15-27.

[8] Bergonzini, J.C. (2004): Climate change, desertification, biological diversity and forest. Silva and Riat.

[9] Biwolé, A.B., Bourland, N., Daïnou, K., Doucet, J.L. (2012): Definition of the ecological profil of Lophira alata: bibliographic synthesis and perspective for futur research. Biotechnology, Agronomy, Society and Environment 16(2): 217-228.

[10] Bonansea, M., Ledesma, C., Rodriguez, M.C. (2016): Assessing the impact of land use and land cover on water quality in the watershed of a reservoir. - Applied Ecology and environmental Research 14(2): 447-456.

[11] Bourland, N., Cerisier, F., Daïnou, K., Smith, A.L., Hubau, W., Beeckman, H., Brostaux, Y., Fayolle, A., Biwolé, A.B., Fétéké, F., Gillet, J.F., Morin-Rivat, J., Lejeune, P., Ntoudé Tiba, E., Van Acker, J., Doucet, J.L. (2015): How tightly linked are Pericopsis elata (Fabaceae) patches to anthropogenic disturbances in southeastern Cameroon? - Forest 6: 293-310.

[12] Chazdon, R.L. (2003): Tropical forest recovery: legacies of human impact and natural disturbances. - Urban and Fischer Verlag 6(1,2): 51-71.

[13] Cheek, M., Cable, S. (2000): Microberlina bisulcata. - In: IUCN 2010. Red list of treatened species (version 2011.2). http://www.iucnredlist.org. Accessed March 2012. 
[14] Choula, F., Priso, R.J., Ndongo, D., Kamdem, J.P., Taffouo, V.D. (2013): Vegetal diversity and structure of one stratum in three sites of Yingui's forest management unit (Cameroon-Central Africa): a comparative study. - International Journal of Plant, Animal and Environmental Sciences 3(4): 105-113.

[15] Dajoz, R. (1965): Precis of ecology. - Bordas, Paris.

[16] Davidson, D.T. (1955): Mechanical analysis of soils. - Lowa Engineering Experiment Station, Rep. No. 21.

[17] Debere, N., Lemessa, F., Urgessa, K., Berecha, G. (2014): Influence of combined application of inorganic-N and organic-P fertilizers on growth ot young tea plant (Camellis sinensis var. assamica) in humid growing area of SW Ethiopia. - Journal of Agronomy 13(4): 179-186.

[18] Douglas, L.A., Weaver, R.W. (1993): Distribution of fixed-N and nitrate-N in cowpea during pod development. - International Plant Nutrition Colloquium, Perth.

[19] Ducan, R.S, Chapman, C.A. (1999): Seed dispersal and potential forest succession in abandoned agriculture in Tropical Africa. - Ecological Applications 9(3): 998-1008.

[20] Duryea, M.L. (2000): Forest regeneration method: natural regeneration, direct seeding and planting. - Institute of Food and Agricultural Sciences, University of Florida, Gainesville.

[21] Fayolle, A., Ouédraogo, D.Y., Ligot, G., Daïnou, K., Bourland, N., Tekam, P., Doucet J.L. (2015): Differential performance between two timber species in forest logging gaps and in plantations in Central Africa. - Forest 6: 380-394.

[22] Fokom, R., Teugwa Mofor, C., Nana Wakam, L., Ngonkeu Megapche, E.L., Tchameni, S., Nwaga, D., Rillig, C.M., Amvam Zollo, P.H. (2013): Glomalin, carbon, nitrogen and soil aggregate stability as affected by land use changes in the humid forest zone in South Cameroon. - Applied Ecology and Environnemental Research 11 (4): 581-592.

[23] Fonge B.A., Focho D.A., Egbe E.A., Tening A.S., Fongod A.N., Neba G.A and Mvondoze A. (2011): The effect of climate and edaphic factors on plant colonisation of lava flows on Mount Cameroon. - Journal of Ecology and Natural Environment 3(8): 255-267.

[24] Gay, K. (1993). Rainforests of the world. A reference handbook. - ABC-CLIO.

[25] Graf, C., Böll, A., Graf, F. (2003): Plants to fight against erosion and landslide surfaces. - Federal Institute of Research WSL, Birmensdorf.

[26] Guariguata, M.R., Ostertag, R. (2000): Neotropical secondary forest succession: changes in structural and funtional characteristics. - Forest Ecology and Management 148: 185206.

[27] Holl, K.D. (1999): Factors limiting tropical rain forest regeneration in abandoned pasture: seed rain, seed germination, microclimate and soil. - Biotropica 31(2): 229-242.

[28] Hossner, L.R., Juo, A.S.R. (1999): Soil nutrient management for sustained food crop production in upland farming systems in the tropic. - Food and fertilizer technology centre, Taiwan.

[29] Jackson, M.I. (1958): Soils chemical analysis. - Journal of Plant Nutrition and Soil Science 85(3): 251-252.

[30] Jemo, M., Nolte, C., Tchienkoua, M., Abaidoo, R.C. (2010): Biological nitrogen fixation potential by soybeans in two low-P soils of southern Cameroon. - Nutrient Cycling Agroecocystems 88: 49-58.

[31] Juma, K.A., Van Averbeke (2005): Response of Muxe to N and P availability in pots. In: Proceedings African Crop Science, Kampala, Uganda.

[32] Ibrahim, A., Ntonga, J.C., Mvondo Ze, A.D. (2010): Leaf litter decomposition in tropical rainforest of Ebom, southwest Cameroon: composition among guils classes. - Tropical Ecology 61 (2): 247-254.

[33] Lamb, D. (1994): Forest rehabilitation in the Asia-Pacific Region: past lessons and uncertainties. - Journal of Tropical Forest Science 7(1): 157-170. 
[34] Lemmens, R.H.M.J., Louppe, D. Oteng-Amoako, A.A. (2008): Timbers II. -PROTA Foundation, Wageningen, Netherlands.

[35] Maiti, D.D., Jana, P.K. (1985) : Effect of different levels of nitrogen and phosphorus on yield and yield attributes of sesame1. - Oilseeds Research 2: 252-259.

[36] Masinde, A.A.O., Omolo, P.O. (2007): Evaluation of the effect of selected legumes on cabbage yield in a cabbage legume rotation. - In: Proceedings African Crop Science Conference, El-Minia, Egypt.

[37] Nanganoa, L.T., Ketcha, J.M., Tchakoute, K.H. (2013): Absorption potential of fine fraction of sandy clay loam soil (natural aluminosilicate) for ammonium ion from aqueous solution. - International Journal of Recent Scientific Research 4(12): 2012-2027.

[38] Ndema Nsombo, E., Etame, J., Taffouo, V.D., Bilong P. (2010): Effects of some physical and chemical characteristics of soil on productivity and yield of cowpea (Vigna unguiculata L. Walp.) in coastal region (Cameroon). - African Journal of Environmental Science and Technology 4(3): 108-114.

[39] Ndema Nsombo, E., Ako'o Bengono, F., Etame, J., Ndongo Din, Ajonina, G., Bilong, P. (2016): Effects of vegetation's degradation on carbon stock, morphological, physical and chemical characteristics of soils within the mangrove forest of the Rio del Rey Estuary: Case study-Bamusso (South-West Cameroon). - African Journal of Environmental Science and Technology 10(3): 58-66.

[40] Newbery, D.M., Prins, H.H.T., Brown, N. (1998): Dynamics of tropical communities : 37 th symposium of the British ecological. - Cambridge University Press

[41] Nouck, A.E., Taffouo, V.D., Tsoata, E., Dibong, D.S., Nguemezi, S.T., Gouado, I., Youmbi, E. (2016): Growth, biochemical constituents, micronutrient uptake and yield response of six tomato (Lycopersicum esculentum L.) cultivars grown under salinity stress. - Journal of Agronomy 15: 58-67.

[42] Nsielolo Kitoko, R., Lejoly, J., Aloni Komanda, J. (2015): Forestry of Millettia laurentii De Wild. (Wenge) by microcuttings in Batéké grassland of Ibi/RD Congo. - International Journal of Innovation and Applied Studies 12(1) : 123-131.

[43] Ojiem, J.O., Mureithi, J.G., Okwuosa, E.A. (2000): Integrated use of legume green manure and inorganic fertilizer for increased maize production in mid altitude areas of central Kenya. - Proceedings scientific conference of the soil management and legume research network project.

[44] Ouédraogo, D.Y., Fayolle, A., Daïnou, K., Demaret, C., Bourland, N., Lagoute, P., Doucet, J.L. (2014): Enrichment of logging gaps with a high conservation value species (Pericopsis elata) in a Central African Moist Forest. - Forest 5: 3031-3047.

[45] Parrota, J.A., Turnbull, J.W., Jones, N. (1997): Catalyzing native forest regeneration on degraded tropical lands. - Forestry Ecology and Management 99: 1-7.

[46] Prevel, M.P., Gagnard, J., Gautier, P. (1984): Vegetal analysis in controlling the supply of temperate and tropical plants. Technical and documentation. - Lavoisier, Paris, France.

[47] Roose, E., Sarrailh, J.M. (1990): Erodibility of some tropical soils, twenty years in measuring plot of erosion under natural rainfall. - ORSTOM, Pedological series, XXV(12): 7-30.

[48] Sharma, G.P., Raghubanshi, A.S. (2011): Lantana camara L. invasion in a dry deciduous forest of India. - Applied Ecology and Environnemental Research 9(3): 253-264.

[49] Shehu, H.E., Kwari, J.D., Sandabe, M.K. (2010): Effects of N, P, K fertilizers on yield, content and uptake of N, P and K by sesame (Sesamun indicum). - International Journal of Agriculture and Biology 12: 845-850.

[50] Shmida, A., Wilson, M.V. (1985): Biological determinants of species diversity. - Journal of Biogeography 12: 1-20.

[51] Slocum, M.G., Aide, M., Zimmerman, J.K., Navarro, L. (2004): Natural regeneration of subtropical montane forest after clearing fern thickets in the Dominican Republic. Journal of Tropical Ecology 20: 483-386. 
[52] Stuffins, C.B. (1967): The determination of phosphorus and calcium in feeding-stuffs. Analyst 92: 107-111.

[53] Taffouo, V.D., Tsoata, E., Kenne, M., Priso, R.J., Fonkou, T., Akoa, A. (2010): Effect of nutrient type on chemical composition and dry matter partitioning of cassava (Manihot esculenta Crantz). - Journal of Agricultural Science and Technology 4(4): 96-101.

[54] Wamba, O.F., Taffouo, V.D., Youmbi, E., Ngwene, B., Amougou, A. (2012): Effets of organic and inorganic nutrient sources on the growth, total chlorophyll and yield of three bambara groundnut landraces in the coastal region of Cameroon. - Journal of Agronomy 11(2): 31-42.

[55] Taffouo, V.D., Ngwene, B., Amougou A., Franken P. (2014): Influence of phosphorus application and arbuscular mycorrhizal inoculation on growth, foliar nitrogen mobilization and phosphorus partitioning in cowpea plants. - Mycorrhiza 24: 361-368.

[56] Ward, J.S., Worthley, T.E. (2003): Forest regeneration handbook. A guide for forest owners, harvesting practitioners, and public officials. - New Haven University of Connecticut.

[57] Walkley, L.P., Black, J.A. (1934): An examination of the detjareff method for determining soil organic matter and a proposed modification of the chromic acid titration method. - Soil Science 37: 29-38.

[58] Whitmore, T.C. (1984): Tropical rain forests for the far East. - Oxford University Press, Oxford.

[59] Zapfack, L., Noiha Noumi, V., Dziedjou Kwouossu, P.J., Zemagho, L., Fomete Nembot, T. (2013): Deforestation and carbon stocks in the surroundings of lobéké national park (Cameroon) in the congo basin. - Environment and Natural Resources Research 3(2): 78-86. 